\title{
ENSINO DE LÍNGUAS E MATERIAIS DIDÁTICOS: DA CONCEITUAÇÃO À PRODUÇÃO E ANÁLISE DE UM PROJETO AUTORAL DE LIVRO DIGITAL DE LINGUA PORTUGUESA*
}

Rosivaldo Gomes*

https://orcid.org/0000-0001-8770-6177

Como citar este artigo: GOMES, R. Ensino de línguas e materiais didáticos: da conceituação à produção e análise de um projeto autoral de livro digital de língua portuguesa. Todas as Letras - Revista de Lingua e Literatura, São Paulo, v. 23, n. 1, p. 1-25, jan./abr. 2021. DOI 10.5935/1980-6914/eLETOL2113255

Submissão: abril de 2020. Aceite: julho de 2020.

Resumo: O objetivo deste artigo é apresentar, na primeira parte, a partir de um estudo de caráter qualitativo-descritivo e bibliográfico, algumas definições sobre propostas de materiais didáticos voltados para o ensino de Língua Portuguesa. Em seguida, com base nas discussões teóricas levantadas, apresenta-se uma proposta de projeto autoral de material didático digital elaborado para a didática de ensino de leitura e de produção textual com o gênero notícia digital em uma pesquisa-ação. O material foi elaborado com base em algumas das definições descritas na primeira parte do artigo e nas noções de leitura e escrita como práticas sociais/de letramento e nas abordagens de competências e habilidades oferecidas pela Base Nacional Comum Curricular (BRASIL, 2018) em relação aos objetos/eixos de ensino para Língua Portuguesa.

Palavras-chave: Materiais didáticos. Ensino. Ensino de linguas. Projeto autoral didático. Livro digital. 


\section{INTRODUÇÃO}

$\boldsymbol{S}$ ituado no campo de discussões sobre ensino-aprendizagem de línguas a partir de uma perspectiva discursiva, sócio-histórica, cultural e crítica (FABRÍCIO, 2006; ROJO, 2006; LEURQUIN, 2013), o objetivo central deste artigo é apresentar, por meio de um levantamento bibliográfico, de caráter qualitativo-descritivo, alguns conceitos relativos à definição de materiais didáticos voltados para o ensino de Língua Portuguesa. Desse objetivo desdobram-se dois outros: 1. mostrar como essas definições têm ajudado na constituição de princípios tanto teóricos quanto metodológicos para a elaboração de "modelos diversos" de materiais didáticos e 2. apresentar um projeto autoral de livro em formato digital elaborado para a didática do ensino de leitura e de produção textual do gênero notícia digital.

O material produzido foi organizado com base em algumas das definições apresentadas a partir do levantamento teórico feito, bem como na noção de projetos didático-autorais de materiais de ensino (GOMES, 2017), conceito esse que tem sido adotado nas pesquisas realizadas no Programa de Pós-Graduação em Letras da Universidade Federal do Amapá (Unifap), no âmbito do Grupo de Pesquisa Núcleo de Estudos e Pesquisa Interdisciplinares em Linguística Aplicada (Nepla) e nas pesquisas de iniciação científica vinculadas ao grupo. Foram consideradas também para a organização do projeto didático-autoral do material de ensino as orientações oferecidas pela Base Nacional Comum Curricular (BRASIL, 2018) em relação às habilidades para o trabalho com os eixos de ensino/práticas de linguagem e objetos de conhecimento da área de Língua Portuguesa.

Para o desenvolvimento dos objetivos propostos, na primeira parte do artigo apresentamos uma revisão da literatura a respeito de definições sobre materiais didáticos, partindo-se da ideia de livros didáticos até outras definições e concepções assumidas atualmente por alguns pesquisadores no cenário brasileiro. Com base nas discussões teóricas levantadas, na segunda parte traçamos o percurso metodológico de criação do projeto autoral de material didático para o trabalho de ensino e aprendizagem de leitura e escrita, o qual foi utilizado em uma escola na Região Norte do Brasil. Em seguida, descrevemos o material didático elaborando e discutindo suas potencialidades para um ensino de Língua Portuguesa a partir de atividade de leitura e produção textual do gênero notícia digital. Por fim, apresentamos as considerações finais.

\section{AINDA O LIVRO DIDÁTICO: UM OBJETO DE ESTUDO COMPLEXO E MULTIFACETADO}

Estabelecer um estado da arte sobre determinado tema, objeto de pesquisa ou questão configura-se como um desafio a qualquer pesquisador, pois pode-se incorrer no risco de deixar de fora, no levantamento feito, certos aspectos que para uns seriam relevantes sobre o objeto ou tema estudado, mas que para outros não seriam. Assim, longe de privilegiar certas concepções de materiais didáticos e outras não e, apesar da vasta discussão já existente no contexto brasileiro, nesta seção apresentamos algumas definições sobre materiais didáticos relacionadas aos livros didáticos de Lingua Portuguesa (doravante LDP), contudo não é objetivo deste estudo um levantamento histórico sobre esse tipo de material, tendo em vista os inúmeros trabalhos já realizados. 
Negligenciados como objetos de pesquisa e esquecidos por historiadores e bibliógrafos, como assevera Choppin (2004), os livros didáticos (LDs), tal como a fênix, "renasceram" nos últimos 40 anos e se constituíram como um objeto de investigação sobre o qual inúmeros são os olhares dispensados. Esses materiais deixaram de ser um tema de pouquíssimos estudos, como lamentava Marisa Lajolo em 1982, e se tornaram objeto de estudo e discussão de várias teses, livros, artigos e projetos de pesquisa em todo o Brasil (BUNZEN, 2001), não só nas áreas de Educação, Linguística e Linguística Aplicada, mas também em Sociologia e História, entre outras.

Bunzen (2001), Razzini (2001), Rojo e Batista (2003) e Rojo (2003), já no início dos anos 2000, apresentavam discussões em seus trabalhos sobre o estado da arte a respeito de pesquisas que tratavam sobre materiais didáticos, em especial sobre os LDP, demonstrando como estava esse campo de estudo. Para Bunzen $(2001,2005)$, os livros didáticos podem ser compreendidos como objetos complexos e multifacetados, pois envolvem diversas dimensões tanto em seu processo de produção quanto de uso no contexto das práticas de processo de ensino e aprendizagem em sala de aula.

Além disso, ainda de acordo com Bunzen (2001), estudar o LDP pode parecer, para alguns, "chover no molhado", pois inúmeras foram/são as produções a respeito desse objeto de investigação. Porém, ainda há o que dizer/pesquisar a respeito de LDP, uma vez que existem muitos aspectos relacionados à escolha, mas principalmente em relação à dinâmica de uso desses materiais no contexto escolar que ainda carecem de discussões. Assim, o estudo, a constituição histórica do LDP, bem como a preservação de acervos e os usos desses materiais têm reunido pesquisadores e pesquisadoras em torno de núcleos institucionais, sobretudo em faculdades de Educação, de Letras e de Comunicação, que objetivam analisar desde o projeto gráfico-editorial a objetos de ensino e aspectos ideológicos e culturais presentes nos LDP.

A natureza dessas pesquisas mostra-nos que o LDP pode ser entendido como uma "caixa preta" ou como um "objeto complexo e multifacetado" (BUNZEN, 2005, 2009), historicamente datado, que vem atender a interesses de uma esfera de produção e de circulação e que, dessa situação histórica de produção, retira seus temas, formas de composição e estilo.

No contexto do ensino brasileiro, Rojo e Batista (2003) mostram que o LDP do ensino fundamental, mas também o do ensino médio, tornou-se uma das principais fontes de leitura e de formação de leitores. Nesse sentido, o LDP passou a ser compreendido como um gênero do discurso, conforme Bunzen e Rojo (2005) e Barros-Mendes e Padilha (2005), que, ao ser produzido pelos autores e outros agentes, possui temas (os objetos de ensino), uma expectativa interlocutiva específica (professores e alunos das escolas públicas e privadas, o editor, os avaliadores do Programa Nacional do Livro e do Material Didático - PNLD) e um estilo didático próprio que o insere em contexto sócio-histórico e ideológico não só específico - escolar -, mas social também.

Dessa maneira, é possivel dizer que os LDP não estão configurados a partir de uma abordagem apenas de ensino ou de uma concepção de língua(gem) (como expressão do pensamento, instrumento de comunicação ou interacionista), pois quando se trata tanto do uso desse material quanto do que ocorre em sala de aula, "não há padrões inflexíveis, modelos fixos; na verdade, recorre-se a diversos caminhos teóricos-metodológicos para a condução do processo de ensino-aprendizagem" (MENDONÇA, 2006, p. 200). 
Em estudos mais recentes a respeito de materiais didáticos, Rojo (2013) problematiza o caráter, o papel estruturador e cristalizador dos currículos desempenhados pelo livro didático e por outros materiais impressos. Para a autora, é necessário que novas teorizações possam clarear a ideia do que seria um material didático e o que o compõe.

Com base nessa questão levantada pela autora, na próxima seção, para além da definição de materiais didáticos como LDP, são apresentadas, de forma breve, outras conceituações, oriundas de campos epistemológicos diversos, sobre materiais didáticos voltados para o ensino de línguas. Para isso, são descritos alguns princípios teórico-metodológicos usados por pesquisadores e grupos de pesquisa, tanto no âmbito nacional quanto internacional, para a caracterização desses materiais. Assim, são apresentadas as noções de: 1. modelo didático de gênero (MDG); 2. sequências didáticas (SD); 3. projeto didático de gênero (PDG); e 4. protótipos didáticos de ensino.

Cabe destacar que, nessa seção, a partir da rápida apresentação feita dos princípios teórico-metodológicos trazidos, não se objetiva realizar comparações entre as definições apresentadas, tampouco indicar qual seria a melhor abordagem e/ou orientação metodológica para a elaboração de materiais didáticos, mas, ao contrário, busca-se demonstrar algumas possiveis compreensões existentes, no campo da Linguística Aplicada no Brasil, sobre a elaboração de propostas de materiais didáticos voltados para o ensino de línguas.

\section{OS MODELOS DIDÁTICOS DE GÊNEROS: CONTRIBUIÇÕES DA DIDÁTICA DAS LÍNGUAS}

Modelos didáticos de gênero (MDG) configuram-se como propostas teórico-metodológicas ou ferramentas didáticas (GONÇALVES; FERRAZ, 2014) para o ensino de francês, que foram elaboradas a partir dos estudos de pesquisadores do Grupo Grafe (Groupe de recherche pour l'analyse du français enseigné), da Faculté de Psychologie et des Sciences de l'Éducation (FPSE), da Universidade de Genebra, conhecidos no Brasil como Grupo de Genebra. Esses dispositivos didáticos, voltados para o ensino de francês, ganharam força, também, no contexto brasileiro a partir dos trabalhos pioneiros realizados por pesquisadores do Programa de Pós-Graduação em Linguística Aplicada e Estudos da Linguagem da Pontificia Universidade Católica de São Paulo (Lael/PUC-SP), com base nas releituras teóricas dos trabalhos do Grupo de Genebra.

Pensado para a didática do ensino de produção oral e mais tarde estendido para o estudo da engenharia didática (DE PIETRO; SCHNEUWLY, 2014), o conceito MDG passa a ser central nos estudos de alguns dos pesquisadores que integram o Grupo de Genebra. Um MDG, em tese, funcionaria como um norte para auxiliar no processo de transposição didática [e de didatização] de um determinado gênero de textos retirados das práticas de referências/de linguagem e mobilizado para as práticas de ensino no letramento escolar, ou seja, a "construção desse modelo de gênero permitiria a visualização das dimensões constitutivas do gênero e seleção das que podem ser ensinadas e das que são necessárias para um determinado nível de ensino" (MACHADO; CRISTOVÃO, 2006, p. 556-557).

Nas palavras de Dolz e Schneuwly (2004, p. 71), o MDG favoreceria a "transformação necessária do gênero quando se torna a objeto a ensinar" e, portanto, 
nortearia o processo de ensino-aprendizagem das dimensões ensináveis de um determinado gênero discursivo, já que "o modelo didático de um gênero a ensinar é, em primeiro lugar, um instrumento pragmático forjado no decorrer mesmo de uma prática de engenharia" (DE PIETRO; SCHNEUWLY, 2014, p. 54).

Assim, o MDG serve ao propósito da constituição dos conhecimentos relativos ao gênero a ser primeiro modelizado e, posteriormente, didatizado. Nesse aspecto, os autores destacam ainda que, ao se pensar o ensino de lingua tomando-se por base um gênero e suas dimensões ensináveis, que serão explicitadas a partir de um MDG, devemos primeiramente realizar um mapeamento das capacidades de linguagem (ação, discursiva, linguístico-discursiva e de significação) dos aprendizes envolvidos no processo de ensino-aprendizagem e que terão contato com o gênero a partir do MDG.

Dolz e Schneuwly (1999) salientam também que, considerando-se a expressiva existência de conhecimentos de referência em jogo na elaboração de modelos de um gênero, isto é, de saberes de referências (da academia e de profissionais especialistas), a ação de seleção de um gênero a ser modalizado deve ser compreendida a partir de três momentos ou movimentos em constante interação. O primeiro é a legitimidade, que está correlacionada com os saberes frutos das teorias acadêmicas ou oriundos de especialistas. O segundo é a pertinência, que diz respeito à observação das capacidades de linguagens dos alunos para as finalidades e objetivos da escola e para os processos de ensino/aprendizagem. $\mathrm{E}$, por fim, há a solidarização, que, de acordo com os autores, é tornar coerentes os saberes em função dos objetivos visados.

Sustentando a ideia da necessidade de uma teoria da prática em relação tanto à compreensão quanto à constituição de um MDG, De Pietro e Schneuwly (2014) propõem três dimensões essenciais relacionadas à caracterização de um MDG: como um produto acabado, que do ponto de vista de sua forma ou organização estrutural apresenta cinco componentes essenciais: 1. a definição geral do gênero; 2. os parâmetros do contexto comunicativo; 3. os conteúdos específicos; 4. a estrutura global; 5. as operações linguageiras e suas marcas linguísticas; como resultado de uma construção, que envolve práticas sociais de referências; literatura/saberes a respeito do gênero; as práticas de linguagem dos alunos; e as práticas escolares; e, por fim, como ferramenta que possui uma dupla dimensão:

a) permite, para um público-alvo, construir diferentes atividades de ensino/ aprendizagem $e$ b) permite construir sequências didáticas de ensino/aprendizagem de complexidade crescente e segundo o desenvolvimento dos alunos (DE PIETRO; SCHNEUWLY, 2014, p. 67).

Em síntese, um MDG

[...] apresenta, então, em resumo, duas grandes características: 1) ele constitui uma sintese com objetivo prático, destinada a orientar as intervenções dos professores e 2) ele evidencia as dimensões ensináveis a partir das quais diversas sequências didáticas podem ser concebidas (DOLZ; SCHNEUWLY, 1999).

Nesse sentido, vemos que os MDG possibilitam a criação de sequências didáticas; eles constituem, portanto, o antes, isto é, fazem parte do processo de modelização e do planejamento didático (ROJO, 2001) que possibilitará a criação de uma sequência didática. 


\section{SEgUÊNCIAS DIDÁTICAS: DAS PRESCRIÇõES GENEBRINAS ÀS ADAPTAÇõeS BRASILEIRAS}

Conforme já discutido, uma sequência didática (SD) surge a partir do processo de constituição de um MDG. Também pensada no âmbito das discussões do Grupo de Genebra sobre didática das linguas, essa ferramenta é definida como "uma sequência de módulos de ensino, organizados conjuntamente para melhorar uma determinada prática de linguagem" (DOLZ; NOVERRAZ; SCHNEUWLY, 2004, p. 50).

Ainda conforme esses autores, uma SD apresenta como finalidade a possibilidade de auxiliar os alunos no processo de aprendizagem e de domínio melhor de um gênero discursivo que, após passar pelo processo de modelização, torna-se um objeto de ensino que serve ao trabalho das práticas de linguagem no contexto escolar. Assim, "as sequências didáticas servem, portanto, para dar acesso aos alunos a práticas de linguagem novas ou dificilmente domináveis" (DOLZ; NOVERRAZ; SCHNEUWLY, 2004, p. 97).

Assim, preocupados em apresentar um dispositivo didático voltado para o ensino do oral e do escrito, Dolz, Noverraz e Schneuwly (2004) propuseram a seguinte estrutura básica de uma sequência didática: 1. apresentação da situação, na qual se contextualiza ao aprendiz a tarefa de expressão oral ou escrita que será realizada; 2. elaboração de uma primeira produção do gênero discursivo modalizado - o objetivo é verificar quais capacidades de linguagem já são desenvolvidas pelos alunos e quais ainda precisam ser ampliadas; 3. os módulos, organizados a partir de um conjunto de atividades e exercícios, que permitem ao aprendiz a condução de sua aprendizagem sobre o gênero; e 4. a produção final, na qual o aprendiz pode praticar e desenvolver o conjunto de saberes apreendidos sobre o gênero ao longo dos módulos. Nesse momento, o professor poderá também realizar um processo avaliativo (somativo, mas também formativo) a respeito dos progressos da aprendizagem alcançados pelo aluno a respeito do gênero trabalhado na SD.

As SD tiveram grande impacto no contexto brasileiro a partir de 2004, primeiro pelos seus usos no ensino de textos de gêneros acadêmicos e, posteriormente, pela incorporação de sua definição em documentos oficiais brasileiros voltados ao ensino de Língua Portuguesa, nos livros didáticos e em concursos de produção textual, como é o caso das Olimpíadas de Língua Portuguesa. Além disso, diversas pesquisas têm sido realizadas, conforme pontuam Machado e Cristovão (2006), que, a partir de propostas diversas de MDG, têm ajudado na constituição de materiais didáticos que utilizam ou adaptam a estrutura básica da SD proposta por Dolz, Noverraz e Schneuwly (2004).

Contudo, como destacam Reinaldo e Bezerra (2019), Rojo (2013), entre outros autores, apesar de alguns resultados positivos, as SD apresentam lacunas e insuficiência ${ }^{1}$, levando muitos pesquisadores a realizarem adaptações e/ou proporem novas abordagens para a construção de materiais didáticos autorais. É nesse contexto que surgem os projetos didáticos de gêneros (PDG), conforme se discutirá no próximo tópico.

\footnotetext{
É possível concordar com a ideia de que, no contexto brasileiro, o trabalho com SD apresenta lacunas e insuficiências, tendo em vista que muitas SD focalizam muito mais a estrutura composicional do gênero (características fixas) do que o seu conteúdo (temático) e seu funcionamento e uso em práticas de letramento, o que acarreta certa artificialidade ao gênero e ao trabalho com práticas de linguagem em sala.
} 


\section{ProJeto didÁtico De GÊNERO}

Sustentados por uma concepção de ensino guiada pela pedagogia de projetos, os PDG configuram-se como um dispositivo didático que também tem auxiliado o processo de ensino-aprendizagem de Língua Portuguesa. Essa proposta teórico-metodológica para a elaboração de materiais didáticos foi apresentada por Guimarães e Kersch (2012a, 2012b, 2014, 2015), no âmbito das discussões realizadas na linha de pesquisa Linguagem e Práticas Escolares, do Programa de Pós-Graduação em Linguística Aplicada da Universidade do Vale do Rio dos Sinos (Unisinos). Para essas autoras, "se as sequências didáticas (SD), tais como propostas por Dolz e Schneuwly (2004) aparecem como que recortadas da realidade, pensa-se em projetos de gêneros que emirjam dessa realidade" (GUIMARÃES; KERSCH, 2012a, p. 540). Assim, a partir das experiências de pesquisas realizadas, as autoras definem PDG como:

Um Projeto Didático de Gênero é uma proposta metodológica de didatização de gêneros. Traz como diferencial o fato de ser um projeto, voltado, portanto, para uma sequência de atividades que se realizarão dentro e fora da escola, de forma a garantir que o(s) gênero(s) tratado(s) esteja $(\mathrm{m})$ realmente ligados a uma prática social (GUIMARÃES; KERSCH, 2014, p. 15).

Na conceituação do PDG estão presentes duas noções importantes: de língua (em)como interação e de gêneros do discurso, ambas sustentadas pela perspectiva enunciativo-discursiva bakhtiniana. As autoras recorrem também à visão de gênero de texto a partir da releitura feita pelos teóricos do Interacionismo Sociodiscursivo e da ideia de capacidades de linguagem (BRONCKART, 1999). Além desses conceitos, o PDG é sustentado teoricamente pela ideia de projetos de letramento, tal como o proposto por Kleiman, Ceniceros e Tinoco (2013), em que leitura e escrita configuram-se como práticas discursivas realizadas em situações diversas de letramento.

Ainda na composição estrutural de um PDG, vemos a ressonância do conceito de SD do Grupo de Genebra. Cabe destacar que, apesar da incorporação dessas bases teóricas, Guimarães e Kersch (2012a) defendem que o PDG se configura como um dispositivo peculiar para o processo de ensino-aprendizagem de língua, uma vez que esse dispositivo didático não foca somente o gênero, como fazem as $\mathrm{SD}$, nem se volta, principalmente, para a escrita de um gênero, mas envolve também a leitura e as práticas sociais. Assim,

Para o grupo de Genebra, interessa que o aluno domine o gênero trabalhado na sequência didática; já para o grupo de Kleiman, o resultado final é dar conta da prática que se decidiu exercer, não se atendo ao domínio de um gênero específico (não há, por exemplo, limitação ao número de gêneros ou agrupamentos de gêneros a serem trabalhados). No nosso grupo, a ousadia é ter, sim, um produto final, cuja circulação não se limitará aos muros da escola, mas também pretende que o aluno domine o(s) gênero(s) envolvido(s) na prática em questão (GUIMARÃES; KERSCH, 2012b, p. 24).

Ainda sobre isso, as autoras argumentam que o PDG pode ser visto como

[...] coconstrução de conhecimentos para uma prática social que possa se inscrever em situações significativas para os aprendizes e para seus docentes. 
Diferentes entradas podem originar um projeto dessa natureza: um tema, uma prática social, um gênero (oral ou do escrito), um conteúdo gramatical. De uma ou outra forma, necessariamente estará ligado a uma concepção que entende a linguagem como forma de interação, como trabalho coletivo, social e historicamente situado e, por essa razão, orientado a uma finalidade específica, que se realiza nas práticas sociais existentes, nos diferentes grupos sociais de dada comunidade. Suas características básicas serão o trabalho com a leitura (incluindo leitura do não verbal) numa situação dialógica, numa atitude responsiva ativa (como propõem Voloshinov e Bakhtin). Seu foco será, no máximo, em dois gêneros, numa relação clara com as práticas sociais da comunidade a que se destina (GUIMARÃES; KERSCH, 2012a, p. 36).

No que diz respeito à estruturação, as atividades do PDG partem, inicialmente, do reconhecimento de uma prática social de interesse dos alunos na qual se reconheçam como sujeitos participantes no sentido de produtores e leitores de textos. Com base nesse contexto, elabora-se o MDG e seleciona-se um gênero discursivo para o desenvolvimento das atividades de leitura e de produção a partir de um conjunto de módulos ou oficinas, como as SD. Porém, como ressaltam as autoras, no PDG prioriza-se tanto as práticas sociais que envolvem os gêneros quanto a didatização do gênero em suas dimensões ensináveis. Assim,

Vamos lembrar que não se trata de ensinar um gênero pelo gênero, pelo conhecimento e/ou identificação de suas características composicionais, por exemplo, mas trata-se de ensinar a usar o gênero, apropriar-se dele para agir com eficiência de forma situada, em outras práticas sociais (GUIMARÃES; KERSCH, 2012a, p. 36).

Ainda na composição da estrutura do PDG, é na situação inicial que os alunos são postos em contato com práticas sociais nas quais o gênero se configura como prática linguageira a partir de um texto. Nesse contexto, os alunos são convidados a produzir uma primeira versão ou produção inicial do texto com base em conhecimentos que já apresentam sobre o funcionamento desse gênero em uma dada prática/situação de comunicação. Essa produção servirá para que professor possa realizar um diagnóstico das capacidades de linguagem e para a elaboração das oficinas ou módulos do PDG. Há também a leitura extensiva que perpassa todo o PDG como objeto de ensino-aprendizagem e que levará à produção textual final.

Posteriormente à realização das atividades dos módulos ou oficinas, os alunos deverão ter ampliado suas capacidades de linguagem (ação, linguísticas e linguístico-discursivas) em relação ao funcionamento do gênero como uma prática discursiva para utilização em práticas sociais. As autoras pontuam ainda que uma grade de avaliação, realizada de forma cooperativa (professor e alunos), deve ser criada para avaliação da produção final. Como última etapa há a reescrita da produção final, momento em que o aluno tem contato com seu próprio texto para uma autoanálise e para verificar se ele atende aos parâmetros sociais de uso e circulação como prática discursiva.

Desse modo, o PDG pode ser considerado um forte dispositivo didático que em muito pode ajudar o professor na construção de materiais didáticos autorais voltados para o processo de ensino-aprendizagem de linguas, tendo por base práticas sociais/de letramentos envolvendo um gênero modalizado. 


\section{Protótipo de ensino: estruturas Flexíveis E vazadas de MATERIAIS DIDÁTICOS}

Segundo Rojo (2013, 2017a, 2017b), protótipos de ensino podem ser compreendidos como uma proposta de ensino que apresenta sequências didáticas "flexiveis e de estrutura vazada" (ROJO; MOURA, 2012, p. 8), contendo atividades elaboradas para aula de linguas (materna ou estrangeira) compostas por textos escritos, imagens, infográficos, galeria de imagens estáticas e em movimento e vídeos sobre uma temática ou mesmo temáticas variadas ou de um gênero ou de um conjunto de gêneros, com foco em diversos eixos/objetos de ensino. Ou seja,

[...] um protótipo, em resumo, é um material navegável e interativo, mas com um discurso autoral/professoral que conduza os alunos a um trabalho digital aberto, investigativo e colaborativo, mediado pelo professor, e que abra a esse professor possibilidades de escolha de acervos alternativos ao acervo principal da proposta didática, de maneira a poder acompanhar o trabalho colaborativo dos alunos (ROJO, 2017a, p. 18).

Por ser um protótipo e por ter sequências didáticas "flexíveis e de estrutura vazada", esse material didático proposto não deve ser um material pronto e acabado, fechado em si mesmo, muito pelo contrário. Esse material, conforme proposto por Rojo (2013, 2017a, 2017b), deve ser flexivel para que possa ser preenchido ou modificado por parte daqueles que o utilizarão, nesse caso, pelo professor e pelo aluno, já que embora haja uma seleção de conteúdos, que deve ser feita pelo professor, isso não impede que o aluno traga novos elementos e contribua com a constituição do material.

Além disso, segundo Rojo (2013), por serem digitais e criados em e-books, os protótipos de ensino devem ser interativos e navegáveis e ter uma estrutura hipermidiática, ou seja, ser estruturados por hiperlinks que permitam ao aluno navegar na internet por meio dos links, possibilitando encaminhamentos para o ensino de diversos conteúdos relacionados à área de linguagens.

Se pensados por essa lógica, esses tipos de materiais podem ampliar o ensino-aprendizagem de línguas de forma mais significativa, já que se configuram com características diversas a partir de composições multimodais. Assim, já que o papel da escola é envolver os alunos em práticas de multiletramento buscando o desenvolvimento de práticas de letramento diversas, esse dispositivo didático também se configura como um caminho para o ensino-aprendizagem de linguas.

Com base nos princípios teórico-metodológicos descritos anteriormente, apresenta-se, na próxima seção, o percurso metodológico da elaboração do material a partir da concepção de materiais didáticos que estamos adotando nas discussões no Grupo de Pesquisa Nepla/Unifap, para a produção de projetos autorais de materiais didáticos voltados para a didática do ensino de produção textual e para a didática do ensino de leitura e análise linguística/semiótica.

\section{Metodologia: PERCURSO DE CRIAÇÃo do MATERIAL DidÁtico}

Metodologicamente, a elaboração do material didático produzido organizou-se a partir de uma pesquisa-ação. Nesse sentido de pesquisa, de acordo com Thiollent (2009) e André (1995), uma das primeiras etapas/fases é a exploratória, na qual 
o pesquisador tem contato com a comunidade/campo, objetivando realizar um diagnóstico dos problemas que afetam aquele contexto. Posteriormente, é realizada a elaboração de um conjunto de ações para serem executadas a partir de uma intervenção - no caso deste trabalho, didática - no contexto investigado.

Com base nessa visão de pesquisa-ação e considerando que a ideia central da pesquisa maior, da qual o material aqui apresentado faz parte, era a aplicabilidade deste em um contexto educacional, com a colaboração de um bolsista de iniciação cientifica ${ }^{2}$ foi selecionada uma escola da rede particular de ensino localizada na cidade de Santana (AP). A escolha por essa escola ocorreu em função de ser um estabelecimento de ensino que possuía laboratório de informática, o que possibilitaria o uso do material didático em formato digital, e também por ser uma das poucas escolas que viabilizou a execução da pesquisa de forma integrada, isto é, com a participação da docente regente da turma.

A fase inicial da pesquisa (diagnóstica) foi realizada com 22 alunos, na faixa etária de 12 a 14 anos, de uma turma do $7^{\circ}$ ano do ensino fundamental e com a professora regente, graduada com licenciatura plena em Letras. Para esse primeiro momento, foi elaborado um MDG do gênero notícia, objetivando-se a realização de um levantamento das capacidades e práticas de linguagem que os olhos já possuíam e das que necessitavam ser ampliadas.

Assim, para a constituição tanto do diagnóstico (Quadro 1) quanto do material didático, adotou-se a concepção de MDG, conforme já explicado, e de projetos didático-autorais de materiais de ensino (GOMES, 2017). Um projeto didático-autoral de material de ensino configura-se como um protótipo de ensino aberto (tanto no formato digital quanto no impresso) que permite ao professor, em formação ou já formado, a organização, a partir de um MDG, de um conjunto de atividades sequenciadas voltadas para a didática do ensino, não necessariamente de todas ao mesmo tempo, de práticas de leitura, práticas de análise linguística (semiótica) e práticas de produção textual a partir de processos de construção de sentidos no ensino-aprendizagem de línguas.

Um projeto didático-autoral fundamenta-se nas noções de língua(gem) como prática dialógica, marcada por índices de apreciação de valor. Além disso, convoca-se a ideia de gênero discursivo (BAKHTIN, 2003), como uma construção discursiva socioideologicamente situada em práticas e eventos de letramentos (STREET, 1984, 2003), que são marcados por dimensões tanto culturais quanto ideológicas.

Além dessas abordagens teóricas, na constituição do projeto autoral estão presentes também alguns princípios da Pedagogia dos Multiletramentos a partir da noção de design e da Aprendizagem pelo Design (KALANTZIS; COPE, 2008) Learning by Design - que, por meio de processos de conhecimento, possibilitam e direcionam o aluno a uma aprendizagem significativa - não só de um gênero -, mas de língua(gem) com base naquilo que o aluno já experienciou, conceituou e analisou em práticas de letramento. Com base nesse dispositivo didático, no Quadro 1 apresenta-se a sintese da atividade inicial proposta para o diagnóstico das capacidades e práticas de linguagem dos alunos em relação ao gênero notícia.

Agradeço a Daniel de Almeida Brandão, à época de realização da presente pesquisa, acadêmico do curso de Letras Português-Francês da Unifap e bolsista de iniciação científica CNPq, pela participação e contribuição na coleta de parte dos dados da pesquisa que gerou o material didático apresentado neste artigo. 
Quadro 1 - Síntese do modelo didático inicial do gênero notícia digital

\begin{tabular}{|c|c|c|}
\hline $\begin{array}{c}\text { Atividade } \\
\text { diagnóstico proposta }\end{array}$ & Objetivos & Gênero modalizado \\
\hline $\begin{array}{l}\text { - Aplicação de um } \\
\text { roteiro de questões } \\
\text { de leitura a partir } \\
\text { de um exemplar de } \\
\text { notícia digital com } \\
\text { questões de } \\
\text { compreensão e } \\
\text { interpretação, } \\
\text { focalizando as quatro } \\
\text { capacidades de } \\
\text { linguagem: ação, } \\
\text { discursivas, } \\
\text { linguístico-discursiva } \\
\text { e de significação. }\end{array}$ & $\begin{array}{l}\text { Objetivos de pesquisa: } \\
\text { - Mapeamento das capacidades de } \\
\text { linguagem já dominadas pelos } \\
\text { alunos em relação ao gênero. } \\
\text { Objetivos didáticos: } \\
\text { - Proporcionar ao aluno a identificação } \\
\text { de aspectos relacionados ao conteúdo } \\
\text { temático, estrutura composicional e } \\
\text { estilo de escrita do gênero notícia; } \\
\text { - Reconhecer características referentes } \\
\text { às condições de produção do gênero } \\
\text { notícia: O produtor do texto: quem } \\
\text { escreve? O objetivo do texto: por que } \\
\text { (para que) escreve? O conteúdo do } \\
\text { texto: sobre o que se escreve? Quem } \\
\text { pode ter interesse pelo texto: para } \\
\text { quem se escreve? Quem lerá o texto? } \\
\text { Onde o texto será lido: em qual lugar } \\
\text { (meio) o texto será lido? }\end{array}$ & $\begin{array}{l}\text { Notícia digital - Tragédia } \\
\text { de Mariana não tem } \\
\text { punidos após mais de } 3 \\
\text { anos, e processo está } \\
\text { parado- Disponível em: } \\
\text { https://g1.globo.com/ } \\
\text { mg/minas-gerais/ } \\
\text { desastre-ambiental-em- } \\
\text { mariana/noticia/2019/ } \\
\text { 03/09/tragedia-de- } \\
\text { mariana-nao-tem- } \\
\text { punidos-apos-mais-de- } \\
\text { 3-anos-e-processo-esta- } \\
\text { parado.ghtml } \\
\text { Vídeo complementar da } \\
\text { notícia. }\end{array}$ \\
\hline
\end{tabular}

Fonte: Elaborado pelo autor.

Assim, primeiramente, realizou-se a elaboração de um MDG com o gênero notícia digital, tendo como temática desastres ambientais, mais precisamente a tragédia de Mariana. A escolha por essa temática partiu da ideia de prática situada (COPE; KALANTZIS, 2000), isto é, relacionada com as vivências dos alunos, pois na cidade onde a escola está localizada ocorreu também um desastre ambiental e social com um porto que realizava exportação de minérios de uma grande empresa estrangeira.

O MDG foi composto por um conjunto de atividades de leitura, compreensão e intepretação textual para a primeira fase da pesquisa-ação (diagnóstica) e foi configurado de forma não extensiva, pois se intentava, a partir dele, apenas a realização de um diagnóstico das capacidades e práticas de linguagem já dominadas ou não pelos alunos a respeito do gênero. A atividade foi elaborada com a participação da professora regente da turma, que também indicou algumas lacunas observadas no trabalho de leitura realizado com os alunos.

Feita a descrição do percurso metodológico da pesquisa para a elaboração do material, na próxima seção apresenta-se o livro didático digital elaborado e a descrição de algumas atividades que o compõem.

\section{Projeto autoral de protótipo de livro digital com o gênero NOTÍCIA PARA O ENSINO DE LÍNGUA PORTUGUESA}

Antes da apresentação do material e do conjunto de atividades que o compõe, é válido ressaltar que o projeto autoral de material didático foi produzido 
para ser usado em contextos educacionais tanto com acesso à internet quanto sem, já que os vídeos, imagens e animações podem ser armazenados dentro do próprio material. Esse material também pode ser utilizado em smartphones e em tablets.

A elaboração do projeto didático autoral para o gênero notícia digital foi realizado pelo autor deste artigo juntamente com um bolsista de iniciação científica CNPq. A elaboração foi dividida em duas etapas; a primeira diz respeito à modalização do gênero, conforme já apresentado sinteticamente no Quadro 1. Posteriormente, a aplicação da atividade diagnóstica com os alunos foi realizada na segunda etapa, que diz respeito à composição das atividades no software Autor Kotobee.

Assim, para os encaminhamentos da construção do projeto autoral do material didático foram realizados encontros entre o coordenador do projeto e o bolsista para discussões e compartilhamento de bases teóricas com diferentes referências para a elaboração e amadurecimento prático do trabalho. A produção das atividades do material didático interativo iniciou-se a partir do segundo semestre de 2017 até o primeiro semestre de 2018, com a testagem de softwares livres que pudessem comportar tanto imagens estáticas quanto em movimento, vídeos, gifs, podcasts etc.

O objetivo do material era trabalhar um conjunto de atividades sistemáticas que requerem práticas de linguagem e também práticas de multiletramento (práticas letradas multiculturais e multimodais) no trabalho de ensino de lingua a partir de leitura, produção textual e análise linguística/semiótica, com recursos digitais, textos de gêneros multissemióticos e hipermidiáticos.

Com base no MDG, no diagnóstico realizado e em um planejamento envolvendo os objetivos pedagógicos a serem alcançados pelos alunos, os módulos do material abordam a organização do gênero textual/discursivo multimodal notícia digital, seu funcionamento em práticas sociais de letramento e características de sua estrutura composicional, conteúdo temático e estilo. Dado o curto espaço deste texto, apresenta-se a composição geral do material e suas atividades.

O livro se organizou de forma multimodal/multissemiótica com o tema "Notícia digital nas aulas de Língua Portuguesa: vamos publicar?”, contendo quatro capitulos e um conjunto de subseções com atividades de práticas de leitura, práticas de produção textual e práticas de análise linguística/semiótica. 


\section{Quadro 2 - Descrição geral do material didático digital}

\begin{tabular}{|c|c|c|}
\hline \multicolumn{3}{|c|}{ Capitulo I - Conhecendo o gênero notícia } \\
\hline \multicolumn{3}{|c|}{ Seção 1: Noticiando um fato } \\
\hline $\begin{array}{c}\text { Foco do capitulo } \\
\text { (descrição das oficinas/ } \\
\text { atividades) }\end{array}$ & $\begin{array}{l}\text { Atividades/práticas de } \\
\text { linguagem previstas e } \\
\text { habilidades (alunos) }\end{array}$ & $\begin{array}{l}\text { Gêneros que compõem a } \\
\text { parte do capitulo e } \\
\text { capacidades de linguagem } \\
\text { acionadas/trabalhadas }\end{array}$ \\
\hline $\begin{array}{l}\text { 1. Levantamento dos } \\
\text { conhecimentos prévios dos } \\
\text { alunos sobre o gênero notícia, a } \\
\text { partir de perguntas provocadoras. } \\
\text { 2. Apresentação de alguns } \\
\text { aspectos gerais da notícia, tais } \\
\text { como as características referentes } \\
\text { às condições de produção do } \\
\text { gênero notícia: O produtor do } \\
\text { texto: quem escreve? O objetivo } \\
\text { do texto: por que (para que) } \\
\text { escreve? O conteúdo do texto: } \\
\text { sobre o que se escreve? Quem } \\
\text { pode ter interesse pelo texto: para } \\
\text { quem se escreve? Quem lerá o } \\
\text { texto? Onde o texto será lido: em } \\
\text { que lugar (meio) o texto será lido? }\end{array}$ & $\begin{array}{l}\text { Atividades } \\
\text { 1. Atividades/práticas de leitura } \\
\text { e interpretação textual. } \\
\text { 2. Atividades/práticas de análise } \\
\text { linguística/semiótica (leitura } \\
\text { imagética). } \\
\qquad \text { Habilidades } \\
\text { 1. Relacionar o conceito de } \\
\text { notícia a partir do desastre } \\
\text { ambiental de Mariana. } \\
\text { 2. Analisar e interpretar o } \\
\text { minidocumentário do desastre, } \\
\text { considerando os aspectos } \\
\text { semióticos que o compõem } \\
\text { (verbal, visual, sonoro) para a } \\
\text { construção de sentidos. } \\
\text { 3. Saber reconhecer, a partir das } \\
\text { informações oferecidas pelos } \\
\text { textos-base, os impactos no } \\
\text { meio ambiente de um acidente } \\
\text { como o de Mariana. } \\
\text { 4. Compreender os impactos que } \\
\text { o desastre de Mariana teve na } \\
\text { cidade e no ambiente a partir de } \\
\text { duas galerias de imagens, antes } \\
\text { e depois do fato. } \\
\text { 5. Refletir sobre o desastre e } \\
\text { relembrar outros fatos ocorridos } \\
\text { no seu estado parecidos com o } \\
\text { de Mariana. }\end{array}$ & $\begin{array}{l}\text { 1. Minidocumentário } \\
\text { 2. Textos explicativos } \\
\text { (enunciados de explicações } \\
\text { conceituais) } \\
\text { 3. Galeria de imagens } \\
\text { 4. Notícias impressas } \\
\text { (digitalizados no material) } \\
\text { Capacidades de } \\
\text { ação, discursivas, } \\
\text { linguístico-discursivas } \\
\text { e de significação }\end{array}$ \\
\hline
\end{tabular}




\section{Quadro 2 - Descrição geral do material didático digital (continuação)}

\begin{tabular}{|c|c|c|}
\hline \multicolumn{3}{|c|}{ Capítulo I - Conhecendo o gênero notícia } \\
\hline \multicolumn{3}{|c|}{ Seção 2: Reconhecendo um fato } \\
\hline $\begin{array}{c}\text { Foco do capitulo } \\
\text { (descrição das oficinas/ } \\
\text { atividades) }\end{array}$ & $\begin{array}{l}\text { Atividades/práticas de } \\
\text { linguagem previstas e } \\
\text { habilidades (alunos) }\end{array}$ & $\begin{array}{l}\text { Gêneros que compõem a } \\
\text { parte do capítulo e } \\
\text { capacidades de linguagem } \\
\text { acionadas/trabalhadas }\end{array}$ \\
\hline $\begin{array}{l}\text { 1. A compreensão da } \\
\text { configuração textual, discursiva } \\
\text { e imagética de um infográfico de } \\
\text { linha do tempo e sua relação } \\
\text { com um fato noticiado. } \\
2 \text {. O reconhecimento, a partir } \\
\text { de recursos imagéticos, de } \\
\text { mudanças físicas no espaço } \\
\text { terrestre de Mariana após o } \\
\text { desastre. }\end{array}$ & $\begin{array}{l}\text { Atividades } \\
\text { 1. Atividades/práticas de leitura } \\
\text { e interpretação textual. } \\
\text { 2. Atividades/práticas de análise } \\
\text { linguística/semiótica (leitura } \\
\text { imagética). } \\
\qquad \text { Habilidades } \\
\text { 1. Perceber e analisar os recursos } \\
\text { estilísticos e semióticos que } \\
\text { constituem um infográfico na } \\
\text { forma de linha do tempo em } \\
\text { relação a aspectos relativos ao } \\
\text { tratamento da informação, como } \\
\text { a ordenação dos eventos na } \\
\text { constituição do desastre de } \\
\text { Mariana. } \\
\text { 2. Compreender o uso de } \\
\text { recursos persuasivos (como a } \\
\text { elaboração do título, escolhas } \\
\text { lexicais, construções metafóricas, } \\
\text { a explicitação de informação) e as } \\
\text { estratégias de persuasão e apelo } \\
\text { realizadas por meio dos recursos } \\
\text { linguístico-discursivos utilizados } \\
\text { (tempo verbal, jogos de palavras, } \\
\text { metáforas, imagens). } \\
\text { 3. Refletir sobre o processo de } \\
\text { mudança que ocorreu na cidade } \\
\text { de Mariana a partir de um } \\
\text { infográfico temporal/linha do } \\
\text { tempo. }\end{array}$ & $\begin{array}{l}\text { 1. Infográfico no formato de } \\
\text { linha do tempo. } \\
\text { 2. Verbete escolar } \\
\text { explicativo. } \\
\text { Capacidades de } \\
\text { ação, discursivas, } \\
\text { linguístico-discursivas } \\
\text { e de significação }\end{array}$ \\
\hline
\end{tabular}

(continua) 


\section{Quadro 2 - Descrição geral do material didático digital (continuação)}

\begin{tabular}{|c|c|c|}
\hline \multicolumn{3}{|c|}{ Capítulo II - Organização do gênero notícia } \\
\hline \multicolumn{3}{|c|}{ Seção 1: Aconteceu, virou notícia e foi para web! } \\
\hline $\begin{array}{c}\text { Foco do capítulo } \\
\text { (descrição das oficinas/ } \\
\text { atividades) }\end{array}$ & $\begin{array}{l}\text { Atividades/práticas de } \\
\text { linguagem previstas e } \\
\text { habilidades (alunos) }\end{array}$ & $\begin{array}{l}\text { Gêneros que compõem a } \\
\text { parte do capítulo e } \\
\text { capacidades de linguagem } \\
\text { acionadas/trabalhadas }\end{array}$ \\
\hline $\begin{array}{l}\text { 1. A compreensão de diferenças } \\
\text { estruturais e discursivas entre o } \\
\text { gênero reportagem em relação ao } \\
\text { gênero notícia. } \\
2 \text {. O reconhecimento, a partir } \\
\text { de recursos imagéticos, de } \\
\text { mudanças físicas no espaço } \\
\text { terrestre de Mariana após o } \\
\text { desastre. } \\
\text { 3. Identificação dos elementos } \\
\text { basilares da composição de } \\
\text { uma notícia. } \\
\text { 4. Compreensão da noção de } \\
\text { parcialidade e imparcialidade } \\
\text { em um fato noticiado. }\end{array}$ & $\begin{array}{l}\text { Atividades } \\
\text { 1. Atividades/práticas de leitura } \\
\text { e interpretação textual. } \\
\text { 2. Atividades/práticas de análise } \\
\text { linguística/semiótica (leitura } \\
\text { imagética). } \\
\qquad \text { Habilidades } \\
\text { 1. Relacionar a notícia com } \\
\text { outros gêneros, como a } \\
\text { reportagem. } \\
\text { 2. Comparar e conceituar } \\
\text { a notícia e a reportagem. } \\
\text { 3. Identificar os aspetos } \\
\text { organizacionais e linguístico- } \\
\text {-discursivos e semióticos do } \\
\text { gênero notícia e reportagem. } \\
\text { 4. Identificar, nas notícias } \\
\text { trabalhadas, o fato central, suas } \\
\text { principais circunstâncias e } \\
\text { eventuais decorrências. } \\
\text { 5. Reconhecer a impossibilidade } \\
\text { de uma neutralidade absoluta no } \\
\text { relato de fatos e identificar } \\
\text { diferentes graus de parcialidade/ } \\
\text { imparcialidade dados pelo recorte } \\
\text { efetuado e pelos efeitos de sentido } \\
\text { advindos de escolhas feitas pelo } \\
\text { autor, de forma a poder } \\
\text { desenvolver uma atitude crítica } \\
\text { diante dos textos jornalísticos. }\end{array}$ & $\begin{array}{l}\text { 1. Boxes ilustrativos de } \\
\text { conceituação da temática } \\
\text { da seção. } \\
\text { 2. Notícia (Mãe abandona } \\
\text { duas crianças pequenas e } \\
\text { vizinhos chamam a polícia). } \\
\text { 3. Reportagem (Lixo } \\
\text { hospitalar ameaça meio } \\
\text { ambiente e expõe catadores } \\
\text { à contaminação). } \\
\text { 4. Notícia (Professor diz ter } \\
\text { sido agredido ao chamar } \\
\text { atenção de aluno em escola } \\
\text { estadual de Cravinhos, SP). } \\
\text { Capacidades de } \\
\text { ação, discursivas e } \\
\text { linguístico-discursivas }\end{array}$ \\
\hline
\end{tabular}




\section{Quadro 2 - Descrição geral do material didático digital (continuação)}

\begin{tabular}{|c|c|c|}
\hline \multicolumn{3}{|c|}{ Capitulo II - Organização do gênero noticia } \\
\hline \multicolumn{3}{|c|}{$\begin{array}{l}\text { Seção 2: Fique informado! } \\
\text { Proposta de produção } 1\end{array}$} \\
\hline $\begin{array}{c}\text { Foco do capitulo } \\
\text { (descrição das oficinas/ } \\
\text { atividades) }\end{array}$ & $\begin{array}{c}\text { Atividades/práticas de } \\
\text { linguagem previstas e } \\
\text { habilidades (alunos) }\end{array}$ & $\begin{array}{l}\text { Gêneros que compõem a } \\
\text { parte do capítulo e } \\
\text { capacidades de linguagem } \\
\text { acionadas/trabalhadas }\end{array}$ \\
\hline $\begin{array}{l}\text { Possibilitar ao aluno: } \\
\text { 1. A compreensão do objetivo e do } \\
\text { funcionamento de uma galeria de } \\
\text { "fotodenúncias" e "fotolegendas". } \\
\text { 2. Reconhecimento de efeitos de } \\
\text { sentido das imagens escolhidas } \\
\text { para a produção de uma } \\
\text { fotodenúncia. } \\
\text { 3. Orientações para produção de } \\
\text { uma fotodenúncia com relação a } \\
\text { um problema do seu bairro. }\end{array}$ & $\begin{array}{l}\text { 1. Compreender o papel de uma } \\
\text { notícia na sociedade a partir de } \\
\text { curiosidades e fatos noticiados. } \\
\text { 2. Reconhecer a possibilidade } \\
\text { de realizar denúncias a partir de } \\
\text { recursos imagéticos. } \\
\text { 3. Analisar os efeitos de sentido } \\
\text { das imagens escolhidas para a } \\
\text { produção. } \\
\text { 4. Produzir uma fotodenúncia } \\
\text { com base em um problema do } \\
\text { seu bairro a partir da leitura } \\
\text { de notícias referentes a esse } \\
\text { problema. }\end{array}$ & $\begin{array}{l}\text { - Boxes ilustrativos de } \\
\text { conceituação da temática } \\
\text { da seção. } \\
\text { - Imagens ilustrativas. } \\
\text { - Verbete jornalístico. } \\
\text { Capacidades de } \\
\text { ação, discursivas, } \\
\text { linguístico-discursivas } \\
\text { e de significação }\end{array}$ \\
\hline \multicolumn{3}{|c|}{ Capitulo III - Noticia fake news } \\
\hline \multicolumn{3}{|c|}{$\begin{array}{l}\text { Seção 1: Quando a noticia é falsa, e agora? } \\
\text { Seção 2: Algumas dicas de como reconhecer uma fake news }\end{array}$} \\
\hline $\begin{array}{l}\text { 1. Conceituação do que é uma } \\
\text { notícia fake news. } \\
\text { 2. Compreensão do que está por } \\
\text { trás de uma fake news, seus } \\
\text { alvos em potencial e suas } \\
\text { principais consequências. } \\
\text { 3. Análise de exemplares de fake } \\
\text { news por meio de comparações } \\
\text { das informações presentes com } \\
\text { outras fontes. }\end{array}$ & 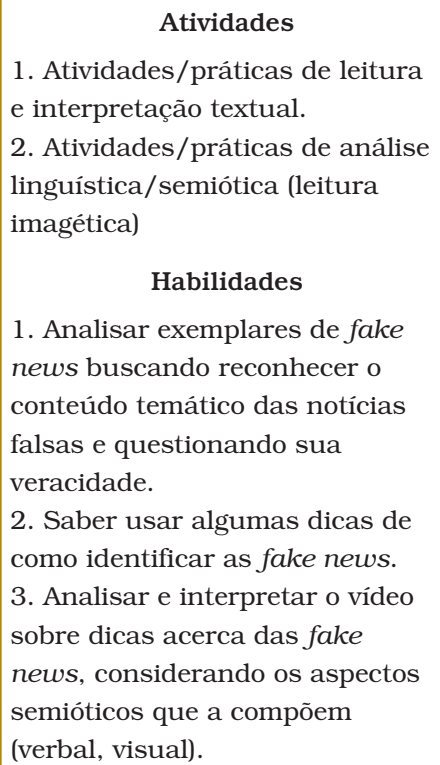 & $\begin{array}{l}\text { - Boxes ilustrativos de } \\
\text { conceituação da temática } \\
\text { da seção. } \\
\text { - Fake news } 1 \text { (É \#Fake } \\
\text { que foto mostra macaco } \\
\text { morto em queimada no } \\
\text { Brasil). } \\
\text { - Fake news } 2 \text { (É \#Fake } \\
\text { que imagem com ilusão } \\
\text { de ótica é teste para } \\
\text { estresse. } \\
\text { - Vídeo de dicas e } \\
\text { instruções. } \\
\text { Capacidades de } \\
\text { ação, discursivas, } \\
\text { linguístico-discursivas } \\
\text { e de significação }\end{array}$ \\
\hline
\end{tabular}




\section{Quadro 2 - Descrição geral do material didático digital (continuação)}

\begin{tabular}{|c|c|c|}
\hline \multicolumn{3}{|c|}{ Capitulo III - Notícia fake news } \\
\hline \multicolumn{3}{|c|}{$\begin{array}{l}\text { Seção 1: Quando a notícia é falsa, e agora? } \\
\text { Seção 2: Algumas dicas de como reconhecer uma fake news }\end{array}$} \\
\hline \multirow[t]{2}{*}{$\begin{array}{c}\text { Foco do capitulo } \\
\text { (descrição das oficinas/ } \\
\text { atividades) }\end{array}$} & $\begin{array}{l}\text { Atividades/práticas de } \\
\text { linguagem previstas e } \\
\text { habilidades (alunos) }\end{array}$ & $\begin{array}{l}\text { Gêneros que compõem a } \\
\text { parte do capitulo e } \\
\text { capacidades de linguagem } \\
\text { acionadas/trabalhadas }\end{array}$ \\
\hline & $\begin{array}{l}\text { 4. Realizar comparações para } \\
\text { checar a confiabilidade da } \\
\text { informação, a manipulação de } \\
\text { fatos e opiniões em diferentes } \\
\text { fontes e mídias, com análise de } \\
\text { sites e serviços checadores de } \\
\text { notícias e com o exercício da } \\
\text { curadoria das informações } \\
\text { oferecidas. }\end{array}$ & \\
\hline \multicolumn{3}{|c|}{ Capitulo IV: Gênero notícia digital e sua produção } \\
\hline \multicolumn{3}{|c|}{ Seção 1: Chegou a hora! Vamos publicar? } \\
\hline $\begin{array}{l}\text { 1. Revisão de alguns aspectos } \\
\text { organizacionais do gênero notícia. } \\
\text { 2. Identificação de aspectos } \\
\text { linguístico-discursivos do gênero } \\
\text { notícia. } \\
\text { 3. Análise e interpretação de uma } \\
\text { notícia a partir de um quiz. } \\
\text { 4. Compreensão do papel social } \\
\text { dos veículos de comunicação na } \\
\text { construção e disseminação de } \\
\text { notícias. }\end{array}$ & $\begin{array}{l}\text { Atividades } \\
\text { 1. Atividades/práticas de leitura } \\
\text { e interpretação textual. } \\
\text { 2. Atividades/práticas de análise } \\
\text { linguística/semiótica (leitura } \\
\text { imagética). } \\
\qquad \text { Habilidades } \\
\text { 1. Revisar alguns aspectos } \\
\text { organizacionais do gênero notícia. } \\
\text { 2. Identificar todos os aspectos } \\
\text { organizacionais e linguístico- } \\
\text {-discursivos do gênero notícia. } \\
\text { 3. Analisar e interpretar uma } \\
\text { notícia a partir de um quiz. } \\
\text { 4. Identificar os aspectos } \\
\text { organizacionais em uma notícia. } \\
\text { 5. Compreender o papel dos } \\
\text { veículos de comunicação na } \\
\text { construção e disseminação de } \\
\text { notícias. }\end{array}$ & $\begin{array}{l}\text { - Boxes ilustrativos de } \\
\text { conceituação da temática } \\
\text { da seção. } \\
\text { - Notícia (De olho na toca). } \\
\text { Capacidades de } \\
\text { ação, discursivas, } \\
\text { linguístico-discursivas } \\
\text { e de significação }\end{array}$ \\
\hline
\end{tabular}




\section{Quadro 2 - Descrição geral do material didático digital (continuação)}

\begin{tabular}{|c|c|c|}
\hline \multicolumn{3}{|c|}{ Capitulo IV: Gênero notícia digital e sua produção } \\
\hline \multicolumn{3}{|c|}{ Seção 2: Retomando as características da notícia (digital) } \\
\hline $\begin{array}{c}\text { Foco do capitulo } \\
\text { (descrição das oficinas/ } \\
\text { atividades) }\end{array}$ & $\begin{array}{c}\text { Atividades/práticas de } \\
\text { linguagem previstas e } \\
\text { habilidades (alunos) }\end{array}$ & $\begin{array}{c}\text { Gêneros que compõem a } \\
\text { parte do capitulo e } \\
\text { capacidades de linguagem } \\
\text { acionadas/trabalhadas }\end{array}$ \\
\hline $\begin{array}{l}\text { 1. Conceituação do gênero notícia } \\
\text { digital. } \\
2 \text {. Compreensão do papel dos } \\
\text { veículos de comunicação na } \\
\text { criação e necessidade de uma } \\
\text { notícia digital. } \\
\text { 3. Reconhecimento das múltiplas } \\
\text { linguagens e recursos digitais e } \\
\text { semióticos envolvidos na } \\
\text { produção de uma notícia digital. }\end{array}$ & $\begin{array}{l}\text { Atividades } \\
\text { 1. Atividades/práticas de leitura } \\
\text { e interpretação textual. } \\
\text { 2. Atividades / práticas de análise } \\
\text { linguística/semiótica (leitura } \\
\text { imagética). } \\
\qquad \text { Habilidades } \\
\text { 1. Conceituar notícia digital. } \\
\text { 2. Compreender o papel dos } \\
\text { veículos de comunicação na } \\
\text { criação e necessidade de uma } \\
\text { notícia digital. } \\
\text { 3. Compreender o papel de uma } \\
\text { notícia digital na sociedade a } \\
\text { partir de curiosidades e } \\
\text { exemplos. } \\
\text { 4. Reconhecer as múltiplas } \\
\text { linguagens e recursos digitais } \\
\text { e semióticos envolvidos na } \\
\text { produção de uma notícia digital. } \\
\text { 5. Analisar e interpretar uma } \\
\text { notícia digital a partir de um quiz. } \\
\text { 6. Identificar os aspectos } \\
\text { organizacionais em uma notícia } \\
\text { digital. } \\
\text { 7. Compreender o papel dos } \\
\text { veículos de comunicação na } \\
\text { construção e disseminação de } \\
\text { notícias digitais. }\end{array}$ & $\begin{array}{l}\text { - Boxes ilustrativos de } \\
\text { conceituação da temática } \\
\text { da seção. } \\
\text { - Notícia (Indígenas } \\
\text { denunciam queimadas } \\
\text { provocadas pela } \\
\text { Eletronorte em área de } \\
\text { reserva do sudeste } \\
\text { do PA). } \\
\text { Capacidades de } \\
\text { ação, discursivas, } \\
\text { linguístico-discursivas } \\
\text { e de significação }\end{array}$ \\
\hline
\end{tabular}

(continua) 


\section{Quadro 2 - Descrição geral do material didático digital (continuação)}

\begin{tabular}{|c|c|c|}
\hline \multicolumn{3}{|c|}{ Capítulo IV: Gênero noticia digital e sua produção } \\
\hline \multicolumn{3}{|c|}{ Seção 3: Chegou a hora de produzir a noticia digital } \\
\hline $\begin{array}{c}\text { Foco do capítulo } \\
\text { (descrição das oficinas/ } \\
\text { atividades) }\end{array}$ & $\begin{array}{l}\text { Atividades/práticas de } \\
\text { linguagem previstas e } \\
\text { habilidades (alunos) }\end{array}$ & $\begin{array}{l}\text { Gêneros que compõem a } \\
\text { parte do capitulo e } \\
\text { capacidades de linguagem } \\
\text { acionadas/trabalhadas }\end{array}$ \\
\hline $\begin{array}{l}\text { 1. Compreensão da estrutura, } \\
\text { situação de comunicação e } \\
\text { intenção comunicacional da } \\
\text { notícia digital. } \\
\text { 2. Análise de efeitos de sentido } \\
\text { das imagens escolhidas para a } \\
\text { produção, assim como o tema. } \\
\text { 3. Compreensão da relação de } \\
\text { um problema do seu bairro } \\
\text { (contexto social local) com o uso } \\
\text { das notícias digitais como meio } \\
\text { de divulgação do problema. } \\
\text { 4. Saber usar a notícia digital } \\
\text { considerando os aspectos } \\
\text { semióticos que a compõem } \\
\text { (verbal, visual). } \\
\text { 5. Produção de exemplares } \\
\text { de notícias digitais. } \\
6 . \text { Organização do layout da } \\
\text { notícia em suporte digital } \\
\text { (disposição gráfica, visual e } \\
\text { verbal-escrita). }\end{array}$ & $\begin{array}{l}\text { Atividades } \\
\text { 1. Atividades/práticas de leitura } \\
\text { e interpretação textual. } \\
\text { 2. Atividades/práticas de análise } \\
\text { linguística/semiótica (leitura } \\
\text { imagética). } \\
\text { 3. Atividade/práticas de } \\
\text { produção textual digital. } \\
\qquad \text { Habilidades } \\
\text { 1. Compreender a estrutura, a } \\
\text { situação de comunicação e } \\
\text { a intenção comunicacional da } \\
\text { notícia digital. } \\
\text { 2. Analisar os efeitos de sentido } \\
\text { das imagens escolhidas para a } \\
\text { produção, assim como o tema. } \\
\text { 3. Saber fazer a relação de um } \\
\text { problema do seu bairro (contexto } \\
\text { social) com o uso das notícias } \\
\text { digitais como meio de divulgação } \\
\text { do problema. } \\
\text { 4. Saber usar a notícia digital } \\
\text { considerando os aspectos } \\
\text { semióticos que a compõem } \\
\text { (verbal, visual). } \\
\text { 5. Saber organizar o layout da } \\
\text { notícia em suporte digital } \\
\text { (disposição gráfica, visual e } \\
\text { verbal-escrita). }\end{array}$ & $\begin{array}{l}\text { - Boxes ilustrativos de } \\
\text { conceituação da temática } \\
\text { da seção. } \\
\text { - Imagens ilustrativas. } \\
\text { Capacidades de ação, } \\
\text { discursivas, } \\
\text { linguístico-discursivas } \\
\text { e de significação }\end{array}$ \\
\hline
\end{tabular}




\section{Quadrro 2 - Descrição geral do material didático digital (conclusão)}

\begin{tabular}{|c|c|c|}
\hline \multicolumn{3}{|c|}{ Capitulo IV: Gênero notícia digital e sua produção } \\
\hline \multicolumn{3}{|c|}{ Seção 3: Chegou a hora de produzir a noticia digital } \\
\hline $\begin{array}{c}\text { Foco do capítulo } \\
\text { (descrição das oficinas/ } \\
\text { atividades) }\end{array}$ & $\begin{array}{l}\text { Atividades/práticas de } \\
\text { linguagem previstas e } \\
\text { habilidades (alunos) }\end{array}$ & $\begin{array}{l}\text { Gêneros que compõem a } \\
\text { parte do capitulo e } \\
\text { capacidades de linguagem } \\
\text { acionadas/trabalhadas }\end{array}$ \\
\hline & $\begin{array}{l}\text { 6. Produzir exemplares de } \\
\text { notícias digitais considerando a } \\
\text { adequação ao contexto de } \\
\text { produção e circulação - os } \\
\text { enunciadores envolvidos, os } \\
\text { objetivos, o suporte, o modo } \\
\text { (escrito ou oral; imagem estática } \\
\text { ou em movimento etc.), a } \\
\text { variedade linguística e/ou } \\
\text { semiótica apropriada a esse } \\
\text { contexto; a construção da } \\
\text { textualidade relacionada às } \\
\text { propriedades textuais e do } \\
\text { gênero. } \\
\text { 7. Organizar a versão final da } \\
\text { notícia, já no suporte digital, } \\
\text { utilizando estratégias de } \\
\text { planejamento, elaboração, } \\
\text { revisão, edição e reescrita/ } \\
\text { redesign, o que inclui fazer } \\
\text { cortes, acréscimos, } \\
\text { reformulações, correções } \\
\text { ortográficas e gramaticais, além } \\
\text { de editar imagens e arquivos } \\
\text { sonoros, efetuar cortes, } \\
\text { acréscimos, ajustes, acrescentar/ } \\
\text { alterar efeitos e promover } \\
\text { ordenamentos. }\end{array}$ & \\
\hline
\end{tabular}

Fonte: Elaborado pelo autor. 


\section{Figura 1 - Capa do protótipo didático}

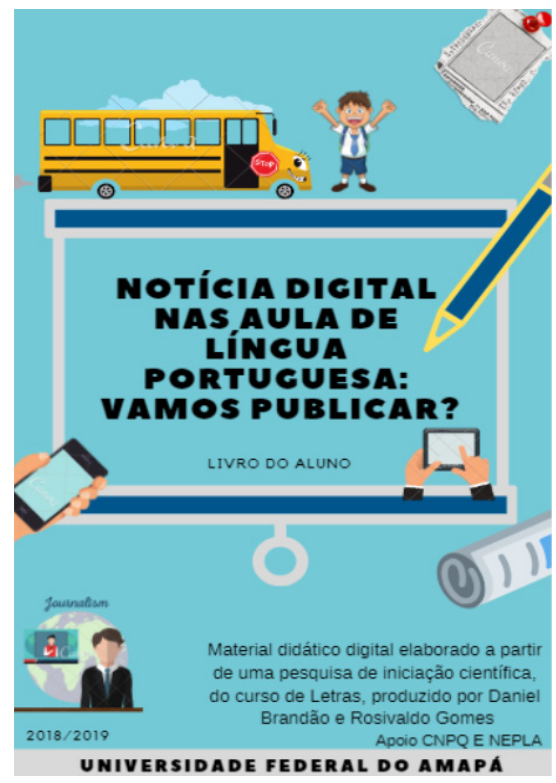

Fonte: Elaborada pelo autor.

Além da capa, o material contém uma apresentação tanto para o aluno quanto para o professor com informações a respeito de como o material poderá ser utilizado (navegação, recursos, objetivos). Detemo-nos, neste momento, no primeiro capítulo, destacando que o foco temático foram questões relacionadas a desastres ambientais, mais precisamente o do rompimento da barragem do distrito de Mariana, em 2015,

Organizados em subseções, os capítulos apresentam um conjunto de textos de um acervo midiático com diversificados gêneros multimodais/multissemióticos (minidocumentário, galeria de imagens/fotos, fotodenúncia, linha do tempo, boxes explicativos). Essa composição multimodal/hipermidiática vai na direção da proposta da pedagogia dos multiletramentos, pois apresenta diversos aspectos de multimodalidade que focam o desenvolvimento de práticas de leitura e produção textual, ou seja, que podem "proporcionar aos alunos uma percepção sobre como padrões de significação são produtos de diferentes contextos" (KALANTZIS; COPE, 2008, p. 205).

Assim, a partir do minidocumentário, da galeria de imagens e da linha do tempo, foram elaboradas diversas atividades de compreensão e interpretação tanto do conteúdo temático tratado nesses gêneros quanto de aspectos de configuração da estrutura composicional multimodal e midiática (montagem a partir de recortes de reportagens, informações coletadas com moradores de Mariana, efeitos sonoros, imagens apresentadas etc.) e do funcionamento dos gêneros em práticas reais de uso da linguagem/de letramentos.

Os capitulos do protótipo apresentam um conjunto de textos contemporâneos que permitem que o professor trabalhe com os alunos atividades que requerem tanto práticas de leitura e intepretação quanto de produção textual (digital) de textos/enunciados multimodais/multissemióticos, com base na apropriação 
de práticas que demandam multiletramentos e letramentos digitais. Além disso, por ser um material aberto, ou seja, guiado não apenas por um gênero, mas por práticas de linguagem, é viável que o professor possa fazer alterações, a depender das necessidades de aprendizagem dos alunos.

\title{
CONSIDERAÇÕES FINAIS
}

A partir do levantamento bibliográfico feito, intentou-se, com este artigo, mostrar como a composição de materiais didáticos autorais tem contribuído para o processo de ensino-aprendizagem no contexto educacional brasileiro. Por esse levantamento é possivel verificar que já dispomos de diversas propostas e princípios teóricos e metodológicos que podem auxiliar o professor tanto no processo de produção quanto no uso de materiais alternativos para o ensino de linguas.

Todavia, a necessidade de produção de materiais didáticos alternativos ou intermediários (ROJO, 2013) para o ensino-aprendizagem de línguas ainda é um tema que precisa ser mais abordado nos cursos de formação de professores, tanto em relação a princípios teóricos que podem auxiliar na construção desses materiais quanto no que diz respeito à análise de materiais existentes, como livros didáticos.

Com relação ao projeto didático-autoral do protótipo de ensino do gênero notícia digital, pode-se observar que esse material apresenta variados aspectos midiáticos, multimodalidade, textos, vídeos, animações etc., o que lhe confere um caráter interativo e hipermidiático que pode ajudar no processo de ensino e aprendizagem de Lingua Portuguesa a partir de práticas de leitura, produção textual e análise linguística/semiótica.

Espera-se que, com esse material e com a discussão aqui proposta, seja possível contribuir para o dificil trabalho de pôr em prática a elaboração de material didático autoral, digital e interativo a partir do qual o professor possa realizar suas ações didáticas para o ensino em sala de aula. Além disso, é fundamental reconhecermos o papel que as tecnologias digitais já assumem em nossa vida diária, e que também podem assumir no trabalho com as aprendizagens dos alunos.

\section{Teaching languages and Materials: FROM CONCEPT to THE PRODUCTION AND ANALYSIS OF AN AUTHORAL PROJECT FOR A DIGITAL BOOK IN THE Portuguese language}

\begin{abstract}
The aim of this article is to present, in the first part, from a qualitative-descriptive and bibliographic study, some definitions on proposals for teaching materials aimed at teaching the Portuguese language. Then, based on the theoretical discussions raised, a proposal for an authorial project of digital didactic material developed for the teaching of reading and textual production with the digital news genre is presented in action research. The material was prepared based on some of the definitions described in the first part of the article and on the notions of reading and writing as social/literacy practices, and on the competencies and skills approaches offered by the Common National Curricular Base (BRASIL, 2018) in relation to teaching objects/axes for the Portuguese language.
\end{abstract}


Keywords: Teaching materials. Teaching. Language teaching. Didactic authorial project. Digital book.

\section{REFERÊNCIAS}

ANDRÉ, M. E. D. A. de. Etnografia da prática escolar. Campinas: Papirus, 1995. BAKHTIN, M. Os gêneros do discurso. In: BAKHTIN, M. Estética da criação verbal. São Paulo: Martins Fontes, 2003. p. 261-306.

BARROS-MENDES, A. N. N.; PADILHA, S. J. Metodologia de análise de livros didáticos de língua portuguesa: desafios e possibilidades. In: COSTA VAL, M. G.; MARCUSCHI, V. B. Livros didáticos de lingua portuguesa: letramento e cidadania. Belo Horizonte: Ceale, Autêntica, 2005. p. 119-145.

BRASIL. Secretaria de Educação Básica. Base Nacional Comum Curricular BNCC. Secretaria de Educação Básica. Brasília: MEC/SEB, 2018.

BRONCKART, J-P. Atividade de linguagem, textos e discursos: por um interacionismo sócio-discursivo. Tradução Anna Rachel Machado e Péricles Cunha. 2. ed. São Paulo: Educ, 1999.

BUNZEN, C. Dinâmicas discursivas na aula de português: os usos do livro didático e projetos didáticos autorais. 2009. 227 f. Tese (Doutorado em Linguística Aplicada) - Universidade Estadual de Campinas, Campinas, 2009.

BUNZEN, C. Livro didático de língua portuguesa: um gênero do discurso. 2005. Dissertação (Mestrado) - Universidade Estadual de Campinas, Campinas, 2005.

BUNZEN, C. O antigo e o novo testamento: livro didático e apostila escolar. Ao Pé da Letra, Recife: UFPE, v. 3, p. 35-46, 2001.

BUNZEN, C.; ROJO, R. H. R. Livro didático de língua portuguesa como gênero do discurso: autoria e estilo. In: COSTA VAL, M. G.; MARCUSCHI, V. B. (org.). Livros didáticos de lingua portuguesa: letramento, inclusão e cidadania. Belo Horizonte: Ceale/Autêntica, 2005. p. 73-117.

CHOPPIN, A. História dos livros e das edições didáticas: sobre o estado da arte. Educação e Pesquisa, São Paulo, v. 30, n. 3, p. 549-566, set./dez. 2004.

COPE, B.; KALANTZIS, M. (ed.) Multiliteracies: literacy learning and the design of social futures. London: Routlege, 2000.

DE PIETRO, J.-F.; SCHNEUWLY, B. O modelo didático de gênero: um conceito da engenharia didática. In: NASCIMENTO, E. L. (org.). Gêneros textuais: da didática de línguas aos objetos de ensino. Campinas: Pontes Editores, 2014. p. 51-81. DOLZ, J.; SCHNEUWLY, B. Os gêneros escolares: das práticas de linguagem aos objetos de ensino. Revista Brasileira de Educação, Anped, n. 11, p. 5-16, maio/ago. 1999.

DOLZ, J.; SCHNEUWLY, B. Gêneros e progressão em expressão oral e escrita: elementos para reflexões sobre uma experiência suiça (francófona). In: SCHNEUWLY, B.; DOLZ, J. Gêneros orais e escritos na escola. Tradução Roxane Rojo e Glaís Sales Cordeiro. Campinas: Mercado de Letras, 2004.

DOLZ, J.; NOVERRAZ, M.; SCHNEUWLY, B. Sequências didáticas para o oral e a escrita: apresentação de um procedimento. In: SCHNEUWLY, B.; DOLZ, J. Gêneros orais e escritos na escola. Tradução Roxane Rojo e Glaís Sales Cordeiro. Campinas: Mercado de Letras, 2004. 
FABRÍCIO, B. F. Linguística aplicada como espaço de "desaprendizagem": redescrições em curso. In: MOITA LOPES, L. P. da. (org.). Por uma linguística aplicada INdisciplinar. São Paulo: Parábola Editorial, 2006. p. 45-63.

GOMES, R. Materiais didáticos digitais e novos (multi)letramentos: caminhos para um webcurrículo. Projeto de pesquisa. Departamento de Pesquisa da Universidade Federal do Amapá, 2017.

GONÇALVES, A. V.; FERRAZ, M. R. R. Ferramentas didáticas e ensino: da teoria à prática de sala de aula. In: NASCIMENTO, E. L. Gêneros textuais: da didática das linguas aos objetos de ensino. Campinas: Pontes Editores, 2014. p. 209-229. GUIMARÃES, A. M. M.; KERSCH, D. F. (org.). Caminhos da construção: projetos didáticos de gênero na sala de aula de língua portuguesa. 1. ed. Campinas: Mercado de Letras, 2012a. v. 1.

GUIMARÃES, A. M. M.; KERSCH, D. F. A caminho da construção de projetos didáticos de gêneros. In: GUIMARÃES, A. M. M.; KERSCH, D. F. (org.). Caminhos da construção: projetos didáticos de gênero na sala de aula de língua portuguesa. 1. ed. Campinas: Mercado de Letras, 2012b. v. 1, p. 21-44.

GUIMARÃES, A. M. M.; KERSCH, D. F. E então... Caminhos da construção de projetos didáticos de gênero: da comunidade de indagação ao desenvolvimento de professoras(es) e das pesquisadoras. In: GUIMARÃES, A. M. M.; KERSCH, D. F. (org.). Caminhos da construção: reflexões sobre projetos didáticos de gênero. 1. ed. Campinas: Mercado de Letras, 2015. v. 3, p. 7-26.

GUIMARÃES, A. M. M.; KERSCH, D. F. Explorando os projetos didáticos de gênero como um caminho metodológico. In: GUIMARÃES, A. M. M.; KERSCH, D. F. (org.). Caminhos da construção: projetos didáticos de gênero no domínio do argumentar. 1. ed. Campinas: Mercado de Letras, 2014. v. 1, p. 17-38.

KALANTZIS, M.; COPE, B. Language education and multiliteracies. In: MAY, S.; HORNBERGER N. H. (ed.). Encyclopedia of language and education. 2. ed. Berlim: Springer Science+Business Media LLC, 2008. v. 1, p. 195-211.

KLEIMAN, A. B.; CENICEROS, R. C.; TINOCO, G. A. Projetos de letramento no ensino médio. In: BUNZEN, C.; MENDONÇA, M. (org.). Múltiplas linguagens para o ensino médio. São Paulo: Parábola Editorial, 2013. p. 69-86.

LEURQUIN, E. V. L. F. Gêneros orais em situação de ensino e aprendizagem de Português Língua Estrangeira. In: GERHARDT, A. F. L. (org.). Ensino-aprendizagem na perspectiva da linguística aplicada. Campinas: Pontes, 2013.

MACHADO, A. R.; CRISTOVÃO, V. L. L. A construção de modelos didáticos de gêneros: aportes e questionamentos para o ensino de gêneros. Revista Linguagem em (Dis)curso - LemD, Tubarão, v. 6, n. 3, p. 547-573, set./dez. 2006.

MENDONÇA, M. Análise linguística no ensino médio: um novo olhar, um outro objeto. In: BUNZEN, C.; MENDONÇA, M. (org.). Português no ensino médio e formação do professor. São Paulo: Parábola Editorial, 2006. p. 199-226.

RAZZINI, M. O espelho da nação: a antologia nacional e o ensino de português e de literatura (1838-1971). 2001. Tese (Doutorado) - Universidade Estadual de Campinas, Campinas, 2001.

ROJO, R. H. R. Novos multiletramentos e protótipos de ensino: por um web-currículo. In: CORDEIRO, G. S.; BARROS, E. M. D.; GONÇALVES, A. V. (org.). Letramentos, objetos e instrumentos de ensino: gêneros textuais, sequências e gestos didáticos. Campinas: Pontes, 2017a. p. 189-216. 
ROJO, R. H. R. Entre plataformas, ODAs e protótipos: novos multiletramentos em tempos de Web2. The ESPecialist: Descrição, Ensino e Aprendizagem, v. 38, n. 1, p. 5-25, jan./jul. 2017b.

ROJO, R. H. R. Fazer linguística aplicada em perspectiva sócio-histórica: privação sofrida e leveza de pensamento. In: MOITA-LOPES, L. P. (org.). Por uma linguistica aplicada INdisciplinar. São Paulo: Parábola Editorial, 2006. p. 253-276.

ROJO, R. H. R. Materiais didáticos no ensino de línguas. In: MOITA-LOPES, L. P. da (org.). Linguistica aplicada na modernidade recente: Festschrift para Antonieta Celani. São Paulo: Parábola Editorial/Cultura Inglesa, 2013. p. 163-195.

ROJO, R. H. R. Modelização didática e planejamento: duas práticas esquecidas do professor? In: KLEIMAN, A. B. (org.). A formação do professor: perspectivas da linguística aplicada. Campinas: Mercado das Letras, 2001. p. 120-148.

ROJO, R. H. R. O perfil do livro didático de língua portuguesa para o ensino fundamental ( $5^{\mathrm{a}}$ a $8^{\mathrm{a}}$ séries). In: ROJO, R.; BATISTA, A. Livro didático de língua portuguesa, letramento e cultura da escrita. Campinas: Mercado de Letras, 2003. p. 69-99.

ROJO, R. H. R.; BATISTA, A. Livro didático de lingua portuguesa, letramento e cultura da escrita. Campinas: Mercado de Letras, 2003.

ROJO, R. H. R.; MOURA, E. Multiletramentos na escola. São Paulo: Parábola, 2012.

STREET, B. Abordagens alternativas ao letramento e desenvolvimento. Apresentado durante a Teleconferência Unesco Brasil sobre 'Letramento e Diversidade', out. 2003.

STREET, B. Literacy in theory and practice. Cambridge: Cambridge University Press, 1984.

THIOLlent, M. Metodologia de pesquisa-ação. São Paulo: Saraiva, 2009. 